\title{
Synthesis, Antimicrobial, and Anticoagulant Activities of 2-(Arylsulfonyl)indane-1,3-diones
}

\author{
Malaichamy Jeyachandran ${ }^{1}$ and Penugonda Ramesh ${ }^{2}$ \\ ${ }^{1}$ Post Graduate and Research Department of Chemistry, Sri Paramakalyani College, Alwarkurichi, Tirunelveli 627 412, India \\ ${ }^{2}$ Department of Natural Products Chemistry, School of Chemistry, Madurai Kamaraj University, Madurai 625 021, India
}

Correspondence should be addressed to Penugonda Ramesh, npc_ramesh@yahoo.co.in

Received 7 April 2011; Accepted 7 June 2011

Academic Editor: William Ogilvie

Copyright ( 2011 M. Jeyachandran and P. Ramesh. This is an open access article distributed under the Creative Commons Attribution License, which permits unrestricted use, distribution, and reproduction in any medium, provided the original work is properly cited.

2-(Arylsulfonyl)indane-1,3-diones, earlier synthesized by Claisen condensation involving diethyl phthalate and aryl methyl sulphones, are found to be potent blood anticoagulants. In search of improved analogs of 2-(arylsulfonyl)indane-1,3-dione, we have synthesized them ( $7 \mathbf{a}-\mathbf{f})$ by a different route involving Knoevenagel reaction between phthalic anhydride and arylsulfonylacetates in the presence of pyridine-piperidine medium for the first time. The synthesized 2-(arylsulfonyl)indane-1,3-diones were evaluated for antimicrobial and anticoagulant activities and all of them registered significant activity.

\section{Introduction}

Indane-1,3-dione and its derivatives constitute a unique group of compounds and attracted the attention of organic chemists and biologist due to their three characteristic features $[1,2]$. (a) Indane-1,3-diones have enormous synthetic potential due to the presence of $\beta$-dicarbonyl moiety which often serves as a synthon for the preparation of more structurally complex compounds via condensation, decomposition, reduction, cyclization, rearrangements, and so forth. (b) The molecule offers wide scope for the study of physiochemical properties such as 1,3-indandione tautomerism, dual reactivity, electrochemical redox properties, unique property of polycrystalline films, and quantum mechanical calculations, and so forth $[3,4]$. (c) A wide range of biological properties covering antimicrobial, antitumor, anti-inflammatory, antiviral, antihepatitis, anticoagulant, rodenticidal, herbicidal, and insecticidal properties were associated with indane-1,3-dione derivatives [5-10].

A survey of literature revealed that derivatives of indane1,3-dione particularly 2-arylsulfonylindane-1,3-diones have been found to be potent blood anticoagulants [11]. Earlier, these were prepared by the Claisen condensation involving diethyl phthalate and aryl methyl sulphones $[12,13]$ by a procedure analogous to the preparation of indane-1,3-dione from diethylphthalate and ethyl acetoacetate [14]. In search of improved oral anticoagulants, we have synthesized 2(arylsulfonyl)indane-1,3-diones $\mathbf{7}$ a-f by a different route involving Knoevenagel reaction between phthalic anhydride and arylsulfonylacetates. The reaction is based on the observation that phthalic anhydride can function as a carbonyl compound in Perkin-type reactions [15].

\section{Chemistry}

In an attempt to prepare improved analogs of 2-(arylsulfonyl)indane-1,3-diones, we have attempted the condensation of arylsulfonylacetic acids with phthalic anhydride under different conditions. Although, the reaction failed with arylsulfonylacetic acids, the corresponding arylsulfonylacetates readily reacted with phthalic anhydride in the presence of pyridine-piperidine medium gave phthalyl arylsulfonylacetates 3 , which on further reaction with sodium ethoxide in dry ethanol and subsequent heating with $1: 1 \mathrm{HCl}$ afforded 2-(arylsulfonyl)indane-1,3-diones 7 a-f (Scheme 1).

The structures of the synthesized compounds 7 a-f were established by IR and NMR spectroscopic data and elemental analysis. Compounds $\mathbf{7}$ a-f were homogenous on TLC and contained sulfur. The presence of sulfone moiety in $7 \mathbf{a}-\mathbf{f}$ 
<smiles>O=C1OC(=O)c2ccccc21</smiles>

1<smiles>[R]COC(=O)CS(=O)(=O)c1ccc([R])cc1</smiles>

2

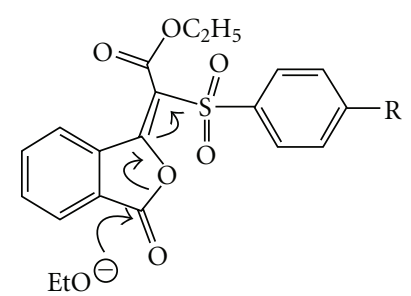

3 a-f

NaOEt/

abs. EtOH<smiles>[R]OC(=O)C1(C(=O)OCC)C(=O)c2ccccc2C1=O</smiles><smiles>[R]c1ccc(S(=O)(=O)C2(C(=O)OCC)C(=O)c3ccccc3C2=O)cc1</smiles>

5 a-f

$\downarrow \mathrm{H}_{2} \mathrm{O}$<smiles>[R]c1ccc(S(=O)(=O)C2(C(=O)[O-])C(=O)c3ccccc3C2=O)cc1</smiles>

6 a-f<smiles>CC(=O)OC(Cl)Cl</smiles><smiles>[R]c1ccc(S(=O)(=O)C2C(=O)c3ccccc3C2=O)cc1</smiles>

$$
\begin{array}{ll}
\text { a: } \mathrm{R}=\mathrm{H} & \mathrm{d}: \mathrm{R}=\mathrm{Br} \\
\text { b: } \mathrm{R}=\mathrm{CH}_{3} & \text { e: } \mathrm{R}=\mathrm{Cl} \\
\text { c: } \mathrm{R}=\mathrm{OCH}_{3} & \text { f: } \mathrm{R}=\mathrm{NO}_{2}
\end{array}
$$

Scheme 1

was established by IR bands [15] in the region, 1300$1360 \mathrm{~cm}^{-1}$ (unsymmetrical $\mathrm{S}=\mathrm{O}$ str.) and $1120-1140 \mathrm{~cm}^{-1}$ (symmetrical S=O str.), and the presence of intact indane1,3dione moiety was also confirmed by the IR bands in the region $1640-1670 \mathrm{~cm}^{-1}$.
The ${ }^{1} \mathrm{H}$ NMR spectra of 7 a-f bear close resemblance and displayed, in addition to complex multiplets due to aromatic protons in the region $\delta 7.0-7.5$, a one proton singlet in the region $\delta 4.0-5.5$ assignable to the lone methine $(\mathrm{H}-$ 2) of indane-1,3-dione moiety; the exact chemical shift of 
TABLE 1: Antibacterial activity of compounds 7 a-f.

\begin{tabular}{|c|c|c|}
\hline \multirow[t]{2}{*}{ Compound } & \multicolumn{2}{|c|}{$\begin{array}{c}\text { Antibacterial activity } \\
\text { (zone of inhibition in } \mathrm{mm} \text { ) at } 10 \mu \mathrm{g} / \mathrm{mL}\end{array}$} \\
\hline & S. aureus & E. coli \\
\hline $7 a$ & 11 & 6 \\
\hline $7 \mathbf{b}$ & 13 & 5 \\
\hline $7 \mathrm{c}$ & 16 & 7 \\
\hline $7 d$ & 15 & 6 \\
\hline $7 e$ & 15 & 5 \\
\hline $7 f$ & 14 & 6 \\
\hline Control (DMSO) & 0 & $\mathbf{0}$ \\
\hline Ciprofloxacin & 19 & 8 \\
\hline
\end{tabular}

TABle 2: Minimum inhibitory concentrations (MICs in $\mu \mathrm{g} / \mathrm{mL}$ ).

\begin{tabular}{lcc}
\hline Compounds & S. aureus & E. coli \\
\hline 7a & 9 & 8 \\
$7 \mathbf{b}$ & 9 & 6 \\
$7 \mathbf{c}$ & 7 & 8 \\
7d & 7 & 6 \\
$7 \mathrm{e}$ & 7 & 8 \\
$7 \mathrm{e}$ & 8 & 6 \\
Ciprofloxacin & 5 & 4 \\
\hline
\end{tabular}

$\mathrm{H}-2$ is influenced by the nature of the substituents of the arylsulfonyl group and by the degree of enolization of the indane-1,3-dione moiety.

\section{Pharmacological Screening}

3.1. Antibacterial Activity. The antimicrobial activity of compounds was determined by the disc diffusion method and minimum inhibitory concentrations (MICs). Minimum inhibitory concentration is the lowest concentration of an antimicrobial agent that inhibits more than $99 \%$ of the bacterial population. MICs were determined by the macrodilution broth method following the procedures recommended by the National Committee for Clinical Laboratory Standards for testing purposes $[16,17]$. Compounds 7 a-f were evaluated in vitro activity against $S$. aureus and $E$. coli at a concentration of $10 \mu \mathrm{g} / \mathrm{mL}$ in meat peptone agar medium. Ciprofloxacin was used as a standard for antimicrobial screening. For each biological activity test, two to three experiments were performed and the average zone of inhibition is shown in Table 1.

Compounds 7c, 7d, 7e, and 7f exhibited significant activity against $S$. aureus while $7 \mathbf{a}, 7 \mathbf{c}, \mathbf{7 d}$, and $\mathbf{7 f}$ showed significant activity against $E$. coli. Compounds $7 \mathbf{a}$ and $7 \mathbf{b}$ showed low activity against $S$. aureus, and $7 \mathbf{b}$ and $7 \mathbf{e}$ registered low activity against E. coli. Compounds 7c and 7d showed significant activity against $S$. aureus and both $E$. coli. The MICs of these two compounds are summarized in Table 2 .

3.2. Anticoagulant Activity. Anticoagulant activity of compounds 7 a-f was assessed against sodium citrate (standard)
TABle 3: Anticoagulant activity of compounds 7 a-f.

\begin{tabular}{lc}
\hline Compound & Clotting time $(\mathrm{min})$ \\
\hline $7 \mathrm{a}$ & 60 \\
$7 \mathrm{~b}$ & 70 \\
$7 \mathrm{c}$ & 65 \\
$7 \mathrm{~d}$ & 75 \\
$7 \mathrm{e}$ & 65 \\
$7 \mathrm{f}$ & 75 \\
Sodium citrate (standard) & $\mathbf{8 0}$ \\
\hline
\end{tabular}

in albino rats $[18,19]$. The blood samples were collected from albino rats by puncturing carotid artery. Compounds 7 a-f and sodium citrate were added to the blood separately $(10 \mathrm{mg} / \mathrm{dL})$. The time required for the formation of the clot was measured, and the results of anticoagulant activity of 7 a-f are shown in Table 3 .

Compounds $\mathbf{7 b}, \mathbf{7 d}$, and $\mathbf{7 f}$ registered high anticoagulant activity compared to that of standard, whereas compounds $7 \mathrm{a}, 7 \mathrm{c}$, and $7 \mathrm{e}$ showed low activity.

\section{Conclusions}

A scrutiny of the results of antibacterial activity of $\mathbf{7}$ a-f reveals (Tables 1 and 2) emphasized that bulky nuclear substituents at 4-position of benzenesulfonyl moiety were found to decrease the antibacterial activity, especially against Grampositive bacteria (S. aureus). Thus there appears to be an empirical inverse relationship between the activity and the size of the nuclear substituents. The observed decreasing order of antibacterial activity of $\mathbf{7}$ a-f against Gram-positive bacteria, $7 \mathrm{c}\left(\mathrm{R}=\mathrm{OMe}, E_{s}=-0.55\right)>7 \mathrm{e}\left(\mathrm{R}=\mathrm{Cl}, E_{s}=-0.97\right)=7 \mathbf{d}$ $\left(\mathrm{R}=\mathrm{Br}, E_{s}=-1.16\right)>7 \mathrm{~b}\left(\mathrm{R}=\mathrm{Me}, E_{s}=-1.24\right) \approx 7 \mathrm{f}$ $\left(\mathrm{R}=\mathrm{NO}_{2}, E_{s}=-2.52\right)$, reflected an empirical inverse correlation between the acidity and Taft's steric factor $\left(E_{s}\right)[20]$ which is a measure of steric bulk of the substituents, and bulky substituents have larger negative values for $E_{s}$.

An analysis of the results of anticoagulant activity of 7 a-f (Table 3 ) revealed that an opposite trend was observed in this case, that is, there is a direct correlation between the anticoagulant activity and the size of the nuclear substituents. Thus, the observed increasing order of anticoagulant activity, $7 \mathbf{f}\left(\mathrm{R}=\mathrm{NO}_{2}, E_{s}=-2.52\right)=7 \mathbf{d}\left(\mathrm{R}=\mathrm{Br}, E_{s}=-1.16\right)>$ $7 \mathbf{b}\left(\mathrm{R}=\mathrm{Me}, E_{s}=-1.24\right)>7 \mathrm{e}\left(\mathrm{R}=\mathrm{Cl}, E_{s}=-0.97\right) \approx 7 \mathrm{c}$ $\left(\mathrm{R}=\mathrm{OMe}, E_{s}=-0.55\right)$, reflected a direct correlation between anticoagulant activity and Taft's steric factor $\left(E_{s}\right)$.

These contrasting results emphasize that bulky groups lower the activity of the compound by preventing it from fitting properly into the binding site of the receptor. On the other hand, bulky substituents may also increase the activity by forcing a compound to adopt the required active conformation at the binding site.

\section{Experimental Section}

Melting points were determined on a sulphuric acid bath and are uncorrected. IR spectra were recorded on JASCO 470 
FT-IR spectrometer, and ${ }^{1} \mathrm{H}-\mathrm{NMR}$ spectra were recorded on a $300 \mathrm{MHz}$ on Bruker (Avance) NMR spectrometer using TMS as an internal standard.

5.1. General Procedure for the Synthesis of Ethyl Arylsulfonylacetate (2). To an alkaline solution of thiophenol $(0.10 \mathrm{~mol}$ in $15 \% \mathrm{NaOH})$, ethyl chloroacetate $(0.10 \mathrm{~mol})$ was added while stirring and keeping the temperature at $0^{\circ} \mathrm{C}$ for about $0.5 \mathrm{~h}$. The resulting oily liquid was extracted with chloroform, and the chloroform layer was washed with water and dried. Evaporation of solvent gave ethyl arylmercaptoacetate, which on oxidation with $m$-CPBA (in $\mathrm{CHCl}_{3}$ ) gave ethyl arylsulfonylacetate 2 .

5.2. General Procedure for the Synthesis of 2-(Arylsulfon$y$ l)Indane-1,3-Diones (7 $\boldsymbol{a}-\boldsymbol{f})$. A mixture of ethyl arylsulfonylacetate $2(0.10 \mathrm{~mol})$, dry pyridine $(15.0 \mathrm{~mL})$, piperidine $(2.0 \mathrm{~mL})$, and powdered phthalic anhydride $1(0.10 \mathrm{~mol})$ was refluxed for $3 \mathrm{~h}$. The reaction mixture was poured into ice water and neutralized with dil. $\mathrm{HCl}$. The solid 3 that separated was filtered, washed with water, and dried. It was then refluxed with sodium ethoxide $(0.20 \mathrm{~mol})$ in absolute ethanol for $1 \mathrm{~h}$, and the excess of solvent was removed in vacuo, and the residue was dissolved in hot water and neutralized while hot with $1: 1 \mathrm{HCl}$. The product 7 a-f that separated on cooling was filtered, dried, and crystallized.

2-(Phenylsulfonyl)-1H-indene-1,3(2H)-dione (7a). M.p. $185^{\circ} \mathrm{C}$ (benzene), yield: 40\%. IR (KBr): 1664 (CO), $1336(\mathrm{~S}=\mathrm{O}$ unsym. str.), 1141 ( $\mathrm{S}=\mathrm{O}$ sym. str.) $\mathrm{cm}^{-1} \cdot{ }^{1} \mathrm{H} \mathrm{NMR}\left(\mathrm{CDCl}_{3}\right)$ : $\delta 4.60\left(\mathrm{~s}, 1 \mathrm{H}, \mathrm{CH}-\mathrm{SO}_{2}-\right) ; 7.24-7.99(\mathrm{~m}, 9 \mathrm{H}, \mathrm{Ar}-\mathrm{H}) .{ }^{13} \mathrm{C}$ $\operatorname{NMR}\left(75 \mathrm{MHz}, \mathrm{CDCl}_{3}\right) \delta_{C}(\mathrm{ppm}): 29.79,122.04,127.19$, $127.49,129.12,132.10,137.10,151.04,179.09$. Anal. Cald. for $\mathrm{C}_{15} \mathrm{H}_{10} \mathrm{O}_{4} \mathrm{~S}$ : C, 62.93; H, 3.52. Found: C, 62.96; H, 3.54.

2-(4-Methylphenylsulfonyl)-1H-indene-1,3(2H)-dione (7b). M.p. $160^{\circ} \mathrm{C}$ (benzene), yield 45\%. IR (KBr): 1672 (CO), 1338 ( $\mathrm{S}=\mathrm{O}$ unsym. str.), 1138 ( $\mathrm{S}=\mathrm{O}$ sym. str.) $\mathrm{cm}^{-1} \cdot{ }^{1} \mathrm{H}$ $\mathrm{NMR}\left(\mathrm{CDCl}_{3}\right): \delta 2.57\left(\mathrm{~s}, 3 \mathrm{H},-\mathrm{CH}_{3}\right), 3.15\left(\mathrm{~s}, 1 \mathrm{H}, \mathrm{CH}-\mathrm{SO}_{2}-\right)$, 7.19-7.52 (m, 8H, Ar-H). Anal. Calcd. for $\mathrm{C}_{16} \mathrm{H}_{12} \mathrm{O}_{4} \mathrm{~S}: \mathrm{C}$, 63.99; H, 4.03. Found: 63.97; H, 4.00.

2-(4-Methoxyphenylsulfonyl)-1H-indene-1,3(2H)-dione (7c). M.p. $153^{\circ} \mathrm{C}$ (pet. ether-benzene), yield 43\%; IR (KBr): 1668 (CO), 1335 ( $\mathrm{S}=\mathrm{O}$ unsym. str.), 1129 ( $\mathrm{S}=\mathrm{O}$ sym. str.) $\mathrm{cm}^{-1}$. ${ }^{1} \mathrm{H} \mathrm{NMR}\left(\mathrm{CDCl}_{3}\right): \delta 3.82\left(\mathrm{~s}, 3 \mathrm{H},-\mathrm{OCH}_{3}\right), 5.86(\mathrm{~s}, 1 \mathrm{H}, \mathrm{CH}-$ $\left.\mathrm{SO}_{2}-\right)$, 6.75-7.49 (m, 8H, Ar-H). Anal. Calcd. for $\mathrm{C}_{16} \mathrm{H}_{12} \mathrm{O}_{5} \mathrm{~S}$ : C, 60.75; H, 3.82. Found: C, 60.77; H, 3.84.

2-(4-Bromophenyl-sulfonyl)-1H-indene-1,3(2H)-dione (7d). M.p. $145^{\circ} \mathrm{C}$ (pet. ether-chloroform), yield $40 \%$. IR ( $\left.\mathrm{KBr}\right)$ : 1656 ( CO), 1346 ( $\mathrm{S}=\mathrm{O}$ unsym. str.), 1136 ( $\mathrm{S}=\mathrm{O}$ sym. str.) $\mathrm{cm}^{-1} .{ }^{1} \mathrm{H} \mathrm{NMR}\left(\mathrm{CDCl}_{3}\right): \delta 4.03\left(\mathrm{~s}, 1 \mathrm{H}, \mathrm{CH}-\mathrm{SO}_{2}-\right), 7.23-7.55$ (m, 8H, Ar-H). Anal. Calcd. for $\mathrm{C}_{15} \mathrm{H}_{9} \mathrm{BrO}_{4} \mathrm{~S}: \mathrm{C}, 49.33 ; \mathrm{H}$, 2.48. Found: C, 49.37; H, 2.51.

2-(4-Chlorophenylsulfonyl)-1H-indene-1,3(2H)-dione (7e). M.p. $131^{\circ} \mathrm{C}$ (pet. ether-chloroform), yield $42 \%$. IR (KBr):
1666 (CO), 1333 ( $\mathrm{S}=\mathrm{O}$ unsym. str.), 1125 ( $\mathrm{S}=\mathrm{O}$ sym. str.) $\mathrm{cm}^{-1} ;{ }^{1} \mathrm{H} \mathrm{NMR}\left(\mathrm{CDCl}_{3}\right): \delta 5.03\left(\mathrm{~s}, 1 \mathrm{H}, \mathrm{CH}-\mathrm{SO}_{2}-\right), 7.25-7.58$ (m, $8 \mathrm{H}, \mathrm{Ar}-\mathrm{H})$. Anal. Calcd. for $\mathrm{C}_{15} \mathrm{H}_{9} \mathrm{ClO}_{4} \mathrm{~S}: \mathrm{C}, 56.17 ; \mathrm{H}$, 2.83. Found: C, 56.14; H, 2.81.

2-(4-Nitrophenylsulfonyl)-1H-indene-1,3(2H)-dione (7f). M.p. $142^{\circ} \mathrm{C}$ (aq. ethanol), yield 41\%. IR (KBr): 1662 (CO), 1328 ( $\mathrm{S}=\mathrm{O}$ unsym. str.), 1119 ( $\mathrm{S}=\mathrm{O}$ sym. str.) $\mathrm{cm}^{-1} \cdot{ }^{1} \mathrm{H} \mathrm{NMR}$ $\left(\mathrm{CDCl}_{3}\right): \delta 4.91\left(\mathrm{~s}, 1 \mathrm{H}, \mathrm{CH}-\mathrm{SO}_{2}-\right), 6.83-7.66(\mathrm{~m}, 8 \mathrm{H}, \mathrm{Ar}-$ $\mathrm{H})$. Anal. Calcd. for $\mathrm{C}_{15} \mathrm{H}_{9} \mathrm{NO}_{6} \mathrm{~S}$ : C, 54.38; H, 2.74; N, 4.23. Found: C, 54.41; H, 2.77; N, 4.19.

\section{Acknowledgments}

The authors thank School of Chemistry for providing FTNMR (under DST-IRHPA programme) data, and one of the authors (M. J.) is grateful to Madurai Kamaraj University for USR fellowship. The authors also thank K. M. College of Pharmacy, Madurai for carrying out biological studies.

\section{References}

[1] G. Dubers, "Organic and physical chemistry of 1,3-indanedione and related compounds," in Progress in Medicinal Chemistry, vol. 10, p. 121, North Holland Publication, New York, NY, USA, 1975.

[2] J. A. Durden, "Biocidal activity of 1,3-indanedione and related compounds," in Progress in Medicinal Chemistry, vol. 10, p. 143, North Holland Publication, New York, NY, USA, 1975.

[3] V. Enchev, G. Ivanova, G. Pavlovi, M. Rogojerov, A. Ahmedova, and M. Mitewa, "Quantum chemical and spectroscopic study of the structure of 2-acetylindan-1,3-dione complexes with metal(II) ions," Journal of Molecular Structure, vol. 654, pp. 11-20, 2003.

[4] A. R. S. Babu, R. Raghunathan, G. Gayatri, and G. N. Sastry, "A highly regioselective synthesis of 1-N-methyl-spiro- [2,3"']oxindole-spiro- $\left[3,2^{\prime \prime}\right]$ indane- $1^{\prime \prime}, 3^{\prime \prime}$-dione-4-arylpyrrolidines through 1,3-dipolar cycloaddition protocol," Journal of Heterocyclic Chemistry, vol. 43, no. 6, pp. 1467-1472, 2009.

[5] V. I. Nikulin, N. Y. Lugovskaya, N. N. Sveshnikov et al., "Imidazole derivatives - synthesis and radioprotective activity of substituted phenacylthioimidazoline and 3-phenyl-5,6dihydroimidazo[2,1-B] thiazole hydrochlorides," Pharmaceutical Chemistry Journal, vol. 28, pp. 13-15, 1994.

[6] M. Katarzyna and B. Magdalena, "Synthesis and pharmacological properties of 5-[ $\alpha$-(1,3-dioxo-2-indanyl)aryl]barbituric acids and 2-(arylmethylene)indan-1,3-diones," Czasopismo Techniczne-Politechnika Krakowska, vol. 104, pp. 105-115, 2007 (Polish).

[7] S. Robert-Piessard, D. Leblois, J. Courant, G. L. E. Baut, and J. Y. Petit, "Synthesis and pharmacological evaluation of 3-(2 and 4- pyridinyl)indane-1,3-diones and structuraly related compounds exerting potential anti-inflammatory and antitumoral activities," Annales Pharmaceutiques Francaises, vol. 56, no. 4, pp. 160-168, 1998.

[8] A. L. F. Fathy, M. M. Mohamaed, and E. Gawish, "Synthesis of heterocycles through reactions of nucleophiles with acrylonitriles. Part 15. Synthesis of some new functionalized benzo $[b]$ pyrans and indeno[1,2- $b]$ pyrans of potential biological activity," Journal of Chemical Research, Synopses, vol. 5, pp. 178-179, 1995. 
[9] M. Mashaly, "One-pot synthesis of new indeno[1,2-b]-4Hpyrans of potential biological activity," Zhonghua Yaoxue Zazhi, vol. 45, pp. 175-177, 1993.

[10] Y. Liu, A. Saldivar, J. Bess et al., "Investigating the origin of the slow-binding inhibition of HCV NS3 serine protease by a novel substrate based inhibitor," Biochemistry, vol. 42, no. 29, pp. 8862-8869, 2003.

[11] B. H. Dieter, "2-[p-(Phenylsulfonyl)phenyl]-1,3-indandione and its tautomer," US 3356732, p 3, 1967.

[12] B. Gabriel and O. Katsuyuki, "Ethyl (Phenylsulfonyl)acetate," in Encyclopedia of Reagents forOrganic Synthesis, vol. 12, p. 1639, John Wiley \& Sons, Chichester, UK, 2001.

[13] L. Horst and P. Heinrich, "1,3-Indandione derivatives," Ger. Patent DE 2045466, p 4, 1972.

[14] B. S. Furniss, A. J. Hannaford, V. Rogers, P. W. G. Smith, and A. R. Tatchell, Vogel's Text Book of Practical Organic Chemistry including Qualatitative Organic Analysis, The English Language Book Society and Longman, London, UK, 4th edition, 1978.

[15] L. F. Fiesher and M. Fiesher, Advanced Organic Chemistry, Van Nostrand Reinhold Company, New York, NY, USA, 1961.

[16] NCCLS: National Committee for Clinical Laboratory Standards, Approved Standard M7-A4, NCCLS, Wayne, Pa, USA, 1997.

[17] NCCLS: National Committee for Clinical Laboratory Standards, Approved Standard M27, NCCLS, Wayne, Pa, USA, 1997.

[18] Remington, Science and Practice of Pharmacy, vol. 2, chapter, Mack Publishing Company, Pa, USA, 1995.

[19] J. L. Miller, Clinical Diagnosis and Management by Laboratory Methods, WB Saunders Company, Philadelphia, Pa, USA, 2001.

[20] C. Hansch and A. J. Leo, Substituent Constants for Correlation Analysis in Chemistry and Biology, John Wiley \& Sons, New York, NY, USA, 1979. 


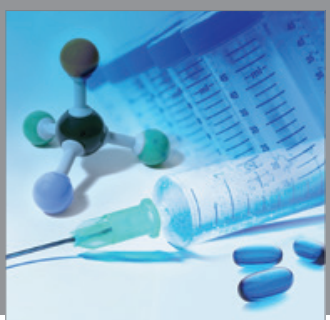

International Journal of

Medicinal Chemistry

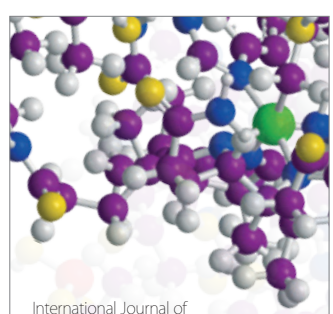

Carbohydrate Chemistry

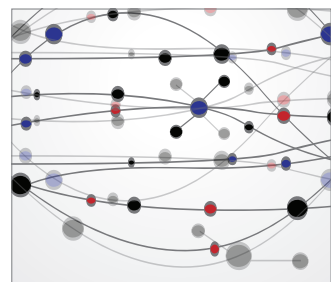

The Scientific World Journal
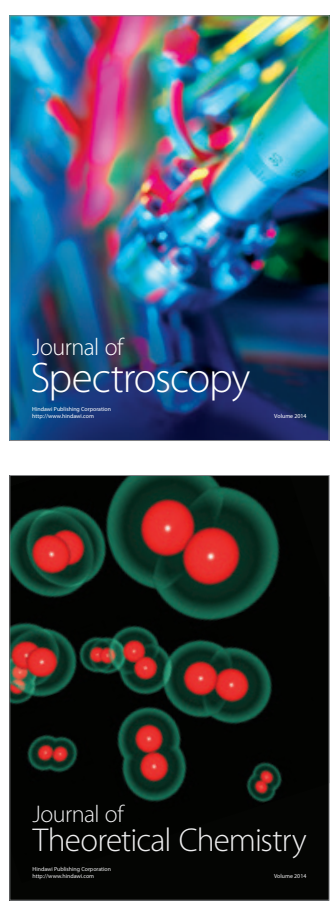
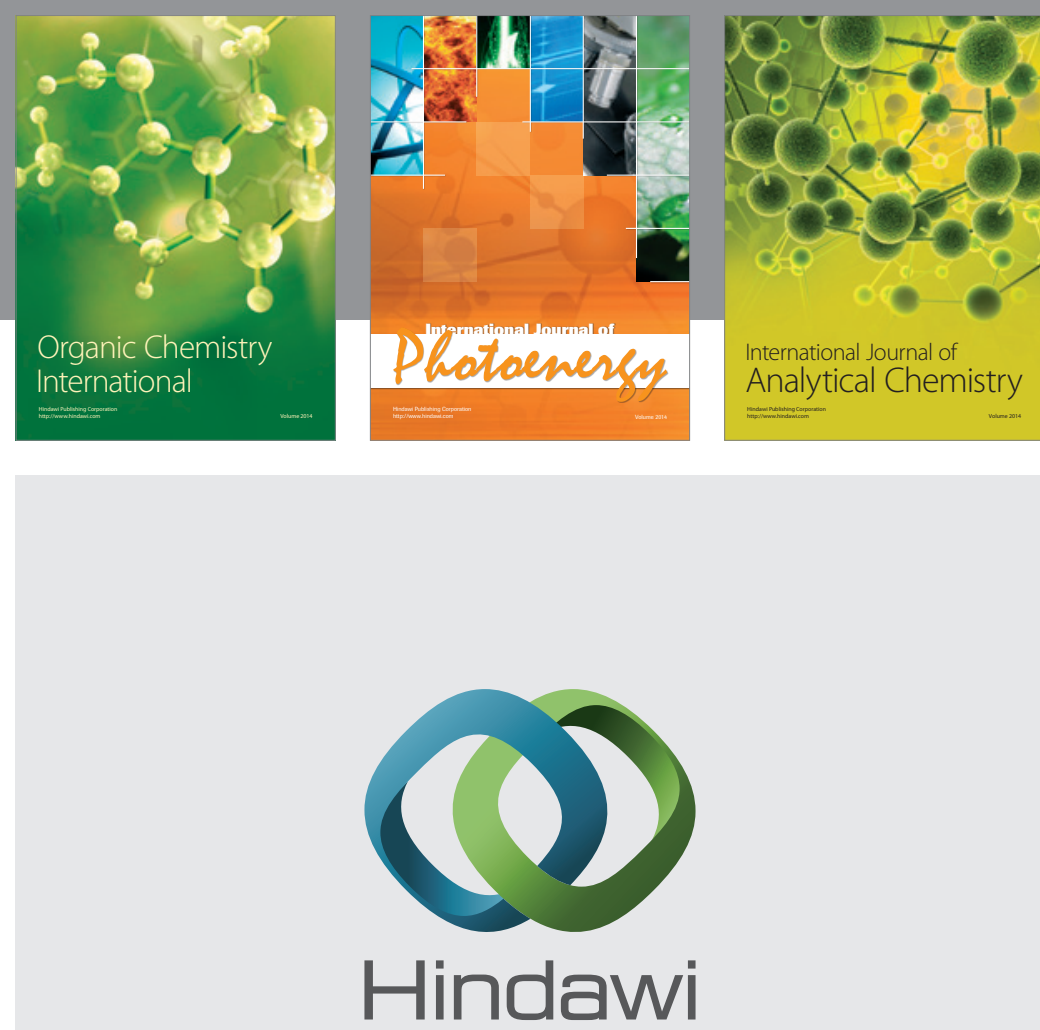

Submit your manuscripts at

http://www.hindawi.com
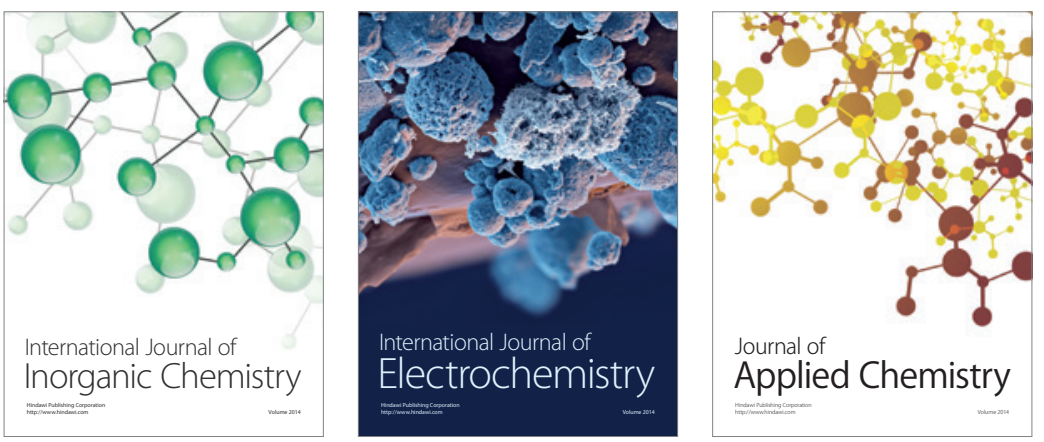

Journal of

Applied Chemistry
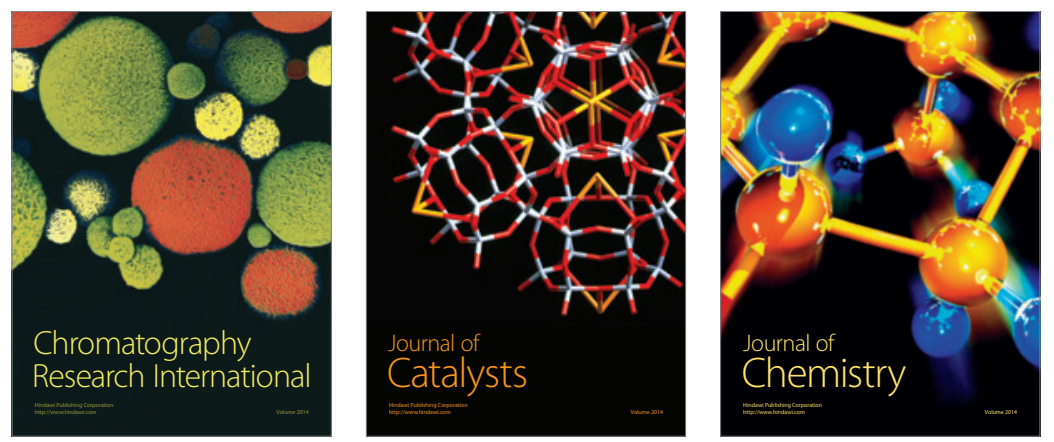
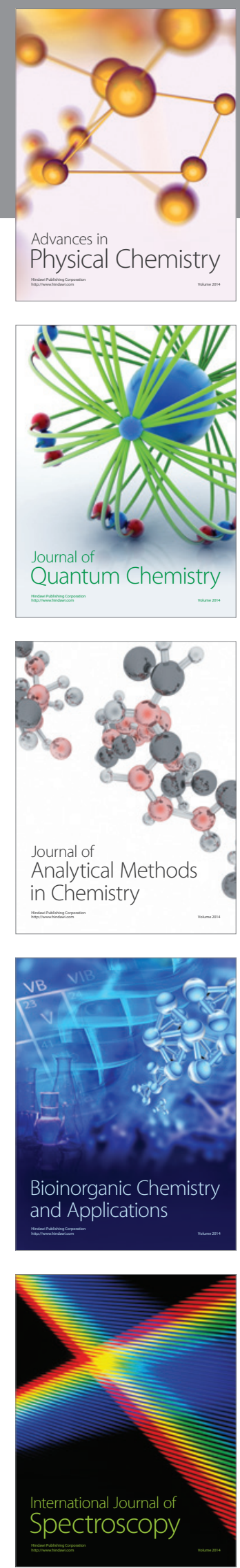